\title{
MEMBANGUN CUSTOMER TRUST MELALUI KUALITAS PELAYANAN PRIMA PADA DIVISI MARKETING SALES TUPPERWARE (SHOWROOM CABANG PONDOK INDAH MALL- JAKARTA SELATAN)
}

\author{
Harjoyo $^{1}$ \\ Dosen Prodi Sekretari D-III Universitas Pamulang \\ harjoyo@yuasabattery.co.id \\ Desilia Purnama Dewi \\ Dosen Prodi Sekretari D-III Universitas Pamulang \\ desiliadewi3@gmail.com \\ Dian Yunitasari ${ }^{3}$ \\ Mahasiswa Prodi Sekretari D-III Universitas Pamulang \\ yunita_dian411@gmail.com
}

\begin{abstract}
ABSTRAK-Penelitian ini membahas mengenai, "Membangun Customer Trust Melalui Kualitas Pelayanan Prima pada Divisi Marketing Sales Tupperware Showroom Cabang Pondok Indah Mall, Jakarta Selatan”. Teknik riset yang digunakan adalah teknik obeservasi dan study pustaka. Adapun tujuannya untuk mendapatkan gambaran akhir hubungan kualitas pelayanan terhadap upaya membangun trust/kepercayaan customer/pelanggan. Untuk dapat memperoleh loyalitas dan kepercayaan pelanggan dengan baik, perusahaan mempunyai mutu servis yang andal dan dikenal dengan istilah pelayanan prima. Servis yang diberikan oleh perusahaan tidak hanya sebatas attitude pekerja dalam melayani pelanggan,tetapi secara komprehensif berlaku terhadap semua layanan pelanggan. Jenjang kepuasan pelanggan pun wajib dilakukan oleh perusahaan, sebab bila pelanggan merasa terpenuhi apa yang menjadi harapannya maka kesetiaan akan muncul dengan sendirinya. Tujuan penelitian ini adalah untuk mengetahui pengaruh kualitas servis yang andal dan unggul terhadap kepercayaan pelanggan.
\end{abstract}

\section{Kata Kunci : Customer Service, Kualitas, Pelayanan Prima}

ABSTRACT- This study discusses "Building Customer Trust Through Excellent Service Quality in the Tupperware Showroom Marketing Sales Division at Pondok Indah Mall Branch, South Jakarta". The research method used is to use the way of observation and literature study. The purpose, to find out how far the influence of service quality on efforts to build trust / customer trust / customers. To be able to obtain customer loyalty and trust well, the company has a good quality of service and today the service activities are known as excellent service. The services provided by the company are not enough just the attitude and behavior of the employees in dealing with customers, but also includes excellent service to achieve customer loyalty The level of customer satisfaction must also be considered by the company, because if the customer feels satisfied the loyalty will naturally arise from customers.The purpose of this study was to determine the effect of excellent service quality on customer trust.

Keywords: Customer Service, Quality, Excellent Service 


\section{PENDAHULUAN}

\section{Latar Belakang}

Saat ini, persaingan dunia bisnis semakin sengit dan sangat dirasakan oleh para pelaku bisnis di Indonesia. Persaingan sudah mulai merambah ke banyak bidang industri, tidak hanya pada dunia retail. Kenyataan menunjukkan bahwa bidang industri lain juga sudah mulai bersaing secara ketat, antara lain industri perlengkapan rumah tangga, elektronik, dan lainnya yang saat ini sudah memiliki jumlah pelanggan yang beragam dari beberapa kalangan yang berbeda. Mulailah perang urat syaraf dan perang harga terjadi lagi di industri ini baik melalui media cetak sampai dengan media elektronik, bahkan sampai persaingan banner dan billboard secara terang-terangan, saling menyerang.

Persaingan dalam dunia bisnis sangatlah penting bagi kehidupan kita. hidup tanpa bersaing sangatlah ketinggalan apalagi dalam dunia bisnis. Terjadinya persaingan usaha dewasa ini tidak bisa dihindari. Dapat dikatakan mustahil sebuah produk/jasa yang dipasarkan tanpa melewati arena persaingan. Dunia pemasaran dewasa ini selain harus bersifat customer oriented juga harus bersifat competition oriented. Bagaimanapun juga, peta persaingan mesti diperhitungkan bila tidak ingin tergilas oleh kegiatan pemasaran perusahaan pesaing.
Secara langsung atau tidak langsung, persaingan bisnis ikut menentukan tingkat keuntungan yang diraih oleh perusahaan.Persaingan itu dapat menyangkut berbagai hal dan bentuk. Di antaranya adalah persaingan untuk memperebutkan kemauan konsumen.

Tidak bisa dipungkiri lagi bahwa pada era globalisasi ini persaingan dalam segala bidang semakin ketat. Tidak ada cara lain untuk bertahan dan memenangkan persaingan kecuali dengan mengembangkan sikap kreatif dan inovatif. dengan bersikap kreatif dan inovatif, kita akan menjadi beda dengan yang lain, menjadi unik dan akan berpotensi menjadi yang terdepan dalam persaingan bisnis dan usaha yang semakin ketat.

Sikap kreatif dan inovatif pada dasarnya dimiliki oleh setiap orang, namun tidak semua orang mampu mengembangkannya. Untuk bisa mengembangkan sikap kreatif dan inovatif diperlukan suatu kesungguhan dan ketekunan.

Persaingan memperebutkan customer di Indonesia sangat ketat. Dengan jumlah perusahaan yang masih tetap banyak dan produk yang di tawarkan perusahaan beragam, kualitas pelayanan memang masih ampuh untuk mempertahankan customer atau mendapatkan customer baru. 
Program pelayanan pada pelanggan dengan bertitik tolak dari konsep kepedulian kepada konsumen terus dikembangakan sedemikian rupa sehingga sekarang ini metide layanan pelanggan merupakan suatu alat utama dalam melakukan strategi marketing dalam menggungguli pesain lainnya. Perhatian yang besar kepada customer dalam manajemen modern telah dikembangkan menjadi suatu pola pelayanan terbaik yang disebut pelayanan prima.

Servis terbaik diberikan oleh setiap Korporat dengan maksud agar customer tidak pindah ke perusahaan sejenis. Untuk menciptakan hal itu bisa dilakukan dengan metode memberikan pelayanan prima.

Keberhasilan pelayanan prima tergantung pada penyelarasan kemampuan, sikap, penampilan, perhatian, tindakan, dan tanggung jawab dalam pelaksanaannya.

Pentingnya pelayanan prima terhadap customer sangat berkaitan dengan bisnis jasa yang dilakukan dalam upaya untuk memberikan kepuasan dan trust growth terhadap pelanggan / customer, Sehingga pelanggan merasa dirinya dipentingkan atau dibutuhkan sehingga harus dlayani dengan baik, bahkan untuk memuaskan customer tidak cukup hanya itu tetapi lebih dari itu memahami bagaimana merespon keinginan customer sehingga dapat menumbuhkan kesan positif dari pelanggan.
Sumber daya manusia yang andal, mempunyai visi yang jauh ke depan dan dapat mengembangkan strategi dan kiat pelayanan prima yang mempunyai keunggulan merupakan kunci sukses pelayanan prima.

Disamping itu harus diupayakan terus-menerus untuk meningkatkan kemampuan para petugas pelayanan agar dapat menumbuhkan dedikasi dan memberikan pelayanan sebaik-baiknya kepada pelanggan untuk tetap setia produk baik barang maupun layanan, tanpa sempat lagi melirik atau memakai produk lain.

Adanya pelayanan yang baik itu membuat customer merasa senang dan menghargai, sehingga customer akan kembali di kemudian hari dan tetap berelasi dengan perusahaan Bahkan akan membagi cerita terkait kepuasan dan kebaikan pelayanan yang didapatkan kepada teman dan saudara lainnya. Dengan demikian dapat mempengaruhi pertumbuhan perusahaan dan menambah peluang atau kesempatan bagi customer service.

Pelaksanaan pelayanan prima oleh pihak perusahaan terhadap para pelanggan, baik itu yang ditujukan untuk pelanggan intern maupun pelanggan ekstern mempunyai peran penting dalam bisnis karena kelangsungan perusahaan sangat tergantung dari loyalitas customer kepada perusahaan. Demikian pula halnya 
pelayanan prima ini yang dilakukan dalam organisasi.

Kepuasan customer merupakan kondisi di mana harapan, keinginan dan kebutuhan pelanggan terpenuhi. Suatu servis dinilai memuaskan apabila servis yang diberikan mampu membuat harapan dan kebutuhan pelanggan terpenuhi. Parameter kepuasan pelanggan merupakan elemen penting dalam menyediakan pelayanan yang prima.Jika pelanggan merasa tidak puas terhadap suatu pelayanan yang disediakan, maka pelayanan yang dimaksud dianggap tidak efektif dan efisien. Hal demikian ini sangat penting bagi pelayanan di bidang retail. Perasaan kepuasan pelanggan terhadap layanan merupakan faktor yang penting dalam pengembangan perusahaan.

Disamping itu kualitas pelayanan prima juga ditentukan oleh seberapa besar kepercayaan pelanggan/customer terhadap produk yang ditawarkan. Semakin produk itu mendapatkan kepercayaan di masyarakat, tentu pelanggan akan bertambah. Pelanggan terbagi dua golongan yaitu pelanggan lama dan pelanggan baru. Kedua pelanggan ini tentu harus mendapatkan perhatian perusahaan atau produsen sesuai karakteristik dan kebutuhan pelanggan dari masing-masing kalangan, sehingga mereka merasakan apa yang menjadi pilihannya dalam membeli produk sesuai dengan harapan. Dalam hal ini akan menumbuhkan kepercayaan (trust).

Tupperware adalah nama produk dapur untuk kebutuhan rumah tangga yang sangat popoler saat ini dan produk Tupperware ini dapat ditemukan di hampir setiap rumah tangga di seluruh dunia. Dengan kekuatan penjualan lebih dari 2 juta dalam lebih dari 100 negara di seluruh dunia. Tupperware terus menawarkan beberapa produk dapur yang paling inovatif. Hal ini memungkinkan perusahaan global jutaan perempuan, dan bahkan pria, untuk memulai dan membangun sendiri bisnis berbasis rumah dan memberikan mereka kesempatan untuk membangun masa depan mereka.

Peneliti tertarik melakukan pengamatan (observasi) berkaitan dengan servis/pelayana yang dilakukan oleh Tupperware, dalam hal ini Tupperware Showroom Cabang Pondok Indah MallJakarta Selatan, karena itu peneliti mengambil judul penelitian "Membangun Customer Trust Melalui Kualitas Pelayanan Prima Pada Divisi Marketing Sales Tupperware (Showroom Cabang Pondok Indah Mall-Jakarta Selatan)”. Berdasarkan Latar Belakang di atas, penulis mengidentifikasikan masalah, sebagai berikut: (1) belum ada upaya konsisten perusahaan untuk menjaga kepercayaan pelanggan; (2) belum ada parameter 
pengukuran tingkat kepuasan pelanggan.

Penulis merumuskan masalah sebagai berikut: (1) upaya apa yang dilakukan oleh Divisi Marketing Sales Tupperware untuk menumbuhkan kepercayaan pelanggan? (2) pelayanan prima apa saja yang dilakukan untuk mempengaruhi tingkat kepuasan pelanggan?

\section{METODE PENELITIAN}

Adapun metodologi penelitian yang digunakan adalah sebagai berikut:

1. Metode Observasi

Metode yang dimaksudkan adalah untuk memperoleh data-data yang dibutuhkan untuk keperluan penulisan tugas akhir.

\section{Analisis Data}

Cara ini digunakan untuk mengidentifikasi masalah-masalah pada sistem yang telah ada dan mencari pemecahan masalah yang akan digunakan selanjutnya.

3. Metode Studi Pustaka

Metode ini dilakukan untuk mencari dan mendapatkan sumber-sumber kajian, landasan teori yang mendukung data-data, atau informasi sebagai acuan dalam melakukan penyusunan laporan.

\section{LANDASAN TEORI}

\section{Pelanggan}

\section{Pengertian Pelanggan (Customer)}

Pelanggan pada dasarnya berasal dari konsumen biasa yang mencoba menggunakan jasa ataupun produk dari sebuah perusahaan. Pelanggan terbentuk dari pola kerja sama saling menguntungkan yang terjadi dalam proses kerja sama antara penyedia layanan dan pengguna layanan. Tanpa kerja sama yang saling menguntungkan tidak akan ada yang disebut sebagai pelanggan. Tanpa kerja sama yang saling menguntungkan yang ada hanyalah proses pembelian barang biasa tanpa diikuti dengan pembelian barang berulang-ulang di waktu lainnya.

\section{Jenis-jenis Pelanggan}

a. Pelanggan Internal

Pelanggan internal merupakan pelanggan yang tidak mengonsumsi suatu barang ataupun jasa secara langsung. Pelanggan tipe ini membeli barang ataupun jasa untuk dijual kembali oleh orang lain. Pelanggan jenis ini dapat menjadi produsen barang atau agen penjualan yang bekerja dengan perusahaan yang menyediakan barang atau jasa.

b. Pelanggan Eksternal

Pelanggan eksternal adalah pelanggan yang secara langsung mengonsumsi barang atau jasa yang mereka beli. Pelanggan jenis ini sering disebut sebagai pelanggan akhir. Pelanggan jenis ini biasanya berhasil didapatkan oleh suatu perusahaan karena kualitas dan kualitas barang atau jasa yang dirasakan oleh pelanggan ini. 


\section{Kepercayaan (Trust)}

Kepercayaan (trustadalah faktor penting yang dapat direalisasikan jika suatu hari itu penting. Kepercayaan adalah faktor penting yang dapat mengatasi kesulitan dan kesulitan di antara mitra bisnis dan juga merupakan aset penting dalam mengembangkan hubungan jangka panjang antar organisasi. Suatu organisasi harus dapat mengenali faktor-faktor yang dapat membentuk kepercayaan ini untuk menciptakan, mengelola, memelihara, mendukung, dan meningkatkan hubungan dengan pelanggan (Zineldin, et. Al., 1997; Zineldin, 1998).

Menurut Peppers dan Rogers (2004: 43), kepercayaan adalah keyakinan salah satu pihak dalam keandalan, daya tahan, dan integritas pihak lain dalam suatu hubungan dan keyakinan bahwa tindakannya adalah dalam kepentingan terbaik dan akan menghasilkan hasil positif bagi pihak yang dipercaya. Kepercayaan penting untuk kesuksesan hubungan.

Manfaat (Benefit relationship) yang didasarkan pada kepercayaan adalah signifikan dan menggambarkan hal-hal berikut:

\section{Cooperation}

Kepercayaan dapat meredakan perasaaan ketidakpastian dan risiko, jadi bertindak untuk menghasilkan peningkatan kerjasama antara anggota relationship. Dengan meningkatnya tingkat kepercayaan, anggota belajar bahwa kerjasama memberikan hasil yang melebihi hasil lebih dari jika dilakukan sendiri.

\section{Komitmen}

Komitmen merupakan komponen yang dapat membangun relationship dan adalah sesuatu yang mudah hilang, yang hanya akan dibentuk oleh pihak-pihak yang saling percaya.

\section{Relationship Duration}

Kepercayaan mendorong anggota relationship bekerja untuk menghasilkan hubungan dan untuk menahan godaan untuk tidak memprioritaskan hasil jangka pendek dan atau bertindak secara oportunistik. Kepercayaan dari penjual secara positif dihubungkan dengan kemungkinan bahwa pembeli akan terlibat dalam bisnis pada waktu di kemudian hari masa yang akan datang, oleh sebab itu memberikan kontribusi untuk meningkatkan durasi relationship.

\section{Pelayanan Prima}

\section{Pengertian Pelayanan Prima}

Di dunia bisnis persaingan antar penjual sangat ketat. Hal inilah yang kemudian mengakibatkan para penjual harus memberikan service yang memuaskan kepada para pelanggannya, karena jika tidak memberikan pelayanan yang baik maka para pelanggannya akan beralih ke yang lainnya. Sebelum membehas lebih lanjut tentang service excellent ada beberapa pengertian tentang pelayanan prima atau service excellent ini antara lain: 
Layanan adalah aktivitas atau urutan kegiatan yang terjadi dalam interaksi langsung antara seseorang dengan orang lain atau mesin secara fisik, dan memberikan keputusan pelanggan. Menuntut layanan Kamus Besar Bahasa Indonesia sebagai upaya melayani kebutuhan orang lain. Padahal melayani membantu mempersiapkan apa yang diperlukan seseorang.

Pelayanan prima merupakan terjemahan istilah "excellent service" yang secara harfiah berarti layanan terbaik atau sangat baik. Disebut sangat bagus atau terbaik karena sesuai dengan standar layanan yang berlaku atau dimiliki oleh penyedia layanan (Yulivia, 2014: 77). Secara sederhana, layanan prima (keunggulan layanan) adalah layanan terbaik dan memenuhi harapan dan kebutuhan pelanggan. dengan kata lain, layanan prima adalah layanan yang memenuhi standar kualitas layanan yang sesuai dengan harapan dan kepuasan pelanggan / komunitas.

\section{Komponen Pelayanan Prima}

Program layanan untuk pelanggan yang dimulai dari konsep merawat konsumen terus dikembangkan sedemikian rupa sehingga sekarang layanan adalah salah satu alat utama dalam menerapkan strategi untuk memenangkan persaingan. Konsep perusahaan peduli atau organisasi untuk memberikan layanan kepada pelanggan didasarkan pada pemahaman tentang peran penting pelanggan dalam kelangsungan hidup dan kemajuan organisasi atau perusahaan. Ini karena konsumen adalah sesuatu yang sangat berharga dimana pada kenyataannya tidak ada satu organisasi pun, terutama perusahaan yang dapat bertahan jika ditinggal oleh pelanggannya. Keberhasilan dalam mengembangkan dan melaksanakan layanan prima tidak lepas dari kemampuan dalam pemilihan konsep pendekatannya, yaitu mengembangkan pelayanan prima dengan menyelaraskan faktor-faktor sikap (Attitude), perhatian (Attention), tindakan (Action), kemampuan (Ability), penampilan (appearance), dan tanggung jawab (accountability)

Dengan maksud ingin memenuhi kepuasan pelanggan walaupun kepuasan sebenarnya sangat relatif tetapi paling tidak seorang frontliner semestinya memiliki pribadi prima yang dapat dilihat dari indikator-indikator, antara lain:
a. Tampil ramah
b. Tampil sopan dan penuh hormat
c. Tampil yakin
d. Tampil rapi
e. Tampil ceria 
f. Tampil senang memaafkan

g. Tenang bergaul

h. Senang belajar dari orang lain

i. Senang pada kewajaran, dan

j. Senang menyenangkan orang lain

\section{HASIL DAN PEMBAHASAN}

Divisi Marketing Sales merupakan fungsi penting dalam suatu perusahaan. Marketing sendiri diartikan pemasaran yang jika diterjemahkan adalah: "Usaha untuk memasyarakatkan hasil produksi perusahaan melalui berbagai cara agar hasil produksi tersebut banyak diminati oleh masyarakat".

Upaya yang dilakukan oleh Divisi Marketing Sales Tupperware untuk menumbuhkan kepercayaan pelanggan antara lain:

1. Meyakinkan calon pelanggan yang diketahui ragu-ragu dalam mengambil keputusan atau menentukan pilihan produk yang akan dibeli.

2. Memotivasi calon pelanggan agar ia bertindak dengan suatu cara yang dikehendaki olehnya yaitu membeli.

3. Mengarahkan sasaran mana dan kepada siapa produk akan ditawarkan dan dijual.

4. Meyakinkan pelanggan atas manfaat dan kelebihan produk yang ditawarkan.

Untuk memudahkan seorang marketing sales dalam upaya menumbuhkan kepercayaan pelanggan, maka harus menguasai beberapa hal yaitu:

1. Product Knowledge

Pengetahuan tentang produk yang meliputi masalah yang berhubungan dengan keadaan fisik, jenis, ukuran, design, dan warna serta manfaat terhadap konsumen, bahkan kelebihannya dengan produk lain yang sejenis.

\section{Price Policy}

Sejenis produk yang ditawarkan atau dijual mempunyai klasifikasi harga. Adanya suatu design harga tertentu yang ditawarkan untuk suatu volume penjualan. Apakah ada insentif tertentu (discount/commission) bagi pembeli.

\section{Human Relation}

Kemampuan tenaga penjual dalam hubungannya dengan masyarakat pasar tertentu untuk mempengaruhi dan pada akhirnya menjadi konsumen. Pendekatan perorangan sangat membantu keberhasilan dengan ditunjang kemampuan berkomunikasi.

Adapun pelayanan prima (Service Excellence) yang di lakukan di Divisi Marketing Sales Tupperware Pondok Indah Mall sebagai berikut:

1. Memberikan pelayanan 3S (Senyum, Salam, Sapa) kepada customer yang berkunjung ke gerai. 
Setiap personal yang ada di Divisi Marketing Sales harus melakukan hal tersebut agar pelanggan merasa dihargai. Pepatah "Pembeli adalah Raja” dijadikan filosofi oleh seluruh karyawan Tupperware, sehingga calon pembeli dan pelanggan merasa nyaman dan dekat.

\section{a. Senyum}

Kenapa harus tersenyum? Karena senyum dapat membuat orang lain bahagia, merasa nyaman, dan dihargai. Senyum itu tidak hanya memerlukan waktu yang singkat, tetapi dapat menimbulkan kesan yang cukup lama.

b. Salam

Salam menciptkan rasa hormat dan keakraban baik bagi karyawan maupun pelanggan.

c. Sapa

Sapa dapat membuat kesan persahabatan dan keakraban

2. Memberikan pelayanan prima kepada pelanggan berdasarkan kosep Attitude (sikap) yang meliputi tiga prinsip berikut:
a. Melayani pelanggan berdasarkan penampilan yang sopan dan serasi.
b. Melayani pelanggan dengan berpikiran positif, sehat, dan logis.
c. Melayani pelanggan dengan sikap menghargai.

3. Memberikan pelayanan prima berdasarkan Attention (Perhatian) meliputi tiga prinsip:

a. Mendengarkan dan memahami secara sungguh-sungguh kebutuhan para pelanggan.

b. Mengamati dan menghargai perilaku para pelanggan.

c. Mencurahkan perhatian penuh kepada pelanggan.

4. Memberikan pelayanan prima berdasarkan Action (Tindakan) meliputi lima prinsip:

a. Mencatat setiap pesanan para pelanggan.

b. Mencatat kebutuhan para pelanggan.

c. Menegaskan kembali kebutuhan para pelanggan.

d. Mewujudkan kebutuhan para pelanggan.

e. Menyatakan terima kasih dengan harapan pelanggan mau kembali.

\section{PENUTUP}

\section{Kesimpulan}

Dari paparan yang sudah dijelaskan pada pembahasan di Bab III, peneliti membuat kesimpulan-kesimpulan sebagai berikut: 
1. Upaya yang dilakukan oleh Divisi Marketing Sales Tupperware untuk menumbuhkan kepercayaan pelanggan antara lain :

a. Meyakinkan calon pelanggan yang diketahui ragu-ragu dalam mengambil keputusan atau menentukan pilihan produk yang akan dibeli.

b. Memotivasi calon pelanggan agar ia bertindak dengan suatu cara yang dikehendaki olehnya yaitu membeli.

c. Mengarahkan sasaran mana dan kepada siapa produk akan ditawarkan dan dijual.

d. Meyakinkan pelanggan atas manfaat dan kelebihan produk yang ditawarkan.

2. Pelayanan prima yang dilakukan dalam mempengaruhi tingkat kepuasan antara lain:

a. Memberikan pelayanan 3S (Senyum, Salam, Sapa) kepada customer yang berkunjung ke gerai.

b. Memberikan pelayanan prima kepada pelanggan berdasarkan kosep Attitude (sikap).

c. Memberikan pelayanan prima berdasarkan Attention (Perhatian).

d. Memberikan pelayanan prima berdasarkan Action (Tindakan).

\section{Saran}

1. Dari Upaya yang dilakukan oleh Divisi Marketing Sales Tupperware untuk menumbuhkan kepercayaan pelanggan yang sudah dilakukan, peneliti memberikan saran agar Tupperware sering mengadakan event penggunaan produk dengan menghadirkan tokoh ternama/selebritis, seprti demo masak menggunakan produk Tupperware, dan sebagainya sehingga pelanggan akan antusias dan tertarik untuk datang ke gerai Tupperware.

2. Peranan pelayanan prima yang dilakukan dalam mempengaruhi tingkat kepuasan pelanggan sebaiknya ditingkatkan dengan mengembangkan SDM yang ada melalui kursus, pelatihan/training seperti Grooming, Beauty Class, dan Sales Strategy sehingga pelayanan prima terhadap pelanggan bertambah baik dan diharapkan akan menaikkan/ meningkatkan jumlah pelanggan Tupperware.

\section{DAFTAR PUSTAKA}

\section{Sumber Buku}

Anderson, E.W. dan Sullivan, M.W. 1993. "The Antecedents and Consequences of Customer Satisfaction for Firms," Marketing Science, Vol. 12 (2), 125- 143.

A. McIlroy and Barnett S. 2000. "Building Customer Relationships: Do Discount Cards Work?" Managing Service Quality, Vol 10. 
Arlan Tjhayadi, Rully. 2006. “Peran Karakteristik Merek, Karakteristik Perusahaan Dan Karakteristik Hubungan Pelanggan-Merek." Jurnal Manajemen, Vol. 6, No.1.

Barnes, James G. 2003. Secrets Of Customer Relationship Management. Yogyakarta: ANDI.

Chan, Syafruddin. 2003. Relationship Marketing: Inovasi Pemasaran yang Membuat Pelanggan Bertekuk Lutut. Jakarta: PT. Gramedia Pustaka Utama.

Don Peppers, Marta Rogers. 2004. Managing Customer Relationship. Canada: Willey.

Ratna Suminar (2017, Vol 4 No. 2) siakses dari: http://openjournal.unpam.ac.id/ index.php/Sekretaris/article/view/822/6 $\underline{84}$ 